\title{
TEMPERATURE INFLUENCE ON KEY PLAYERS OF THE SOMATOTROPIC AXIS OF TENCH, TINCA TINCA (ACTINOPTERYGII: CYPRINIFORMES: CYPRINIDAE)
}

\author{
Remigiusz PANICZ ${ }^{1 *}$, Jacek SADOWSKI ${ }^{1}$, Heike SCHÜTZE ${ }^{2}$, and Sven M. BERGMANN ${ }^{2}$ \\ ${ }^{1}$ Division of Aquaculture, West Pomeranian University of Technology in Szczecin, Poland \\ ${ }^{2}$ Friedrich-Loeffler-Institut, Institute of Infectology, Federal Research Institute for Animal Health, Südufer \\ Greifswald-Insel Riems, Germany
}

\begin{abstract}
Panicz R., Sadowski J., Schütze H., Bergmann S.M. 2015. Temperature influence on key players of the somatotropic axis of tench, Tinca tinca (Actinopterygii: Cypriniformes: Cyprinidae). Acta Ichthyol. Piscat. 45 (4): 335-342.
\end{abstract}

Background. Tench, Tinca tinca (Linnaeus, 1758), has been cultivated in Polish fish farms since centuries, due to its good quality meat. However, the most critical problem in tench culture is the slow growth, which makes farming of this species unprofitable. Growth rates of fish are influenced by numerous internal and external factors such as water temperature, food availability and quality, as well as photoperiod. In order to analyse and improve tench growth rate, the most important factors (GH, IGF-I) of the somatotropic axis should be analysed against selected culture factors. Key elements of the axis play a pivotal role in the coordination of protein and energy metabolism during postnatal growth. Therefore, the aim of this study was to assess effect of water temperature on the activity of somatotropic axis of tench. Obtained results can be useful in tench farming in order to deal with mass gain.

Material and methods. Forty tench, approximately $3+$ years of age, were placed in eight $240 \mathrm{~L}$ tanks, five fish in each tank. There were four temperature regimes $\left(10^{\circ} \mathrm{C}, 15^{\circ} \mathrm{C}, 20^{\circ} \mathrm{C}\right.$, and $\left.25^{\circ} \mathrm{C}\right)$ studied separately for males and females during a period of one week. At the end of the experiment, $2 \mathrm{~mL}$ of blood, the whole pituitary gland, 2 liver samples, and one muscle sample were collected from selected fish specimens. Real-time PCR was used to assess the effect of water temperatures on the level of tench mRNA $g h$ transcripts in pituitary-, liver-, and muscle samples. Also, the concentration of growth hormone (GH) protein was measured in relation to individual temperature treatments in blood plasma and liver samples using ELISA assay.

Results. The highest cycle threshold $(\mathrm{Ct})$ values of mRNA $g h$ were detected in the pituitary samples. ELISA assays confirmed that water temperature affected GH and IGF-I concentrations in the blood and the liver samples. Additionally, results from ELISA assays confirmed sex size dimorphism (SSD) phenomenon in tench.

Conclusion. Presented results shed new light on mechanisms of functioning of tench somatotropic axis and constitute benchmark information for future experiments on nutritional factors.

Keywords: sexual size dimorphism, real-time PCR, fish growth, ELISA, IGF-I, temperature effect

\section{INTRODUCTION}

Fish grow constantly during their morphogenesis and this unique feature has not been observed in the life cycle of avian and mammalian species (Sumpter 1992). Growth is regulated by many known and unknown factors that may act in different pathways and occur at different life stages (Viadero 2005, Handeland et al. 2008, Chang and Wong 2009). Moreover, a complex network of interactions is under strong influence of various external factors, such as water temperature, food availability and quality, photoperiod, to name just a few (Jobling 2002, Mustapha et al. 2012). Receptors (photo, thermal, pressure, or others) transfer environmental signals through specific pathways and influence growth performance of fish (Mader and Cameron 2004, Kullgren et al. 2013). The main role in fish growth is played by the somatotropic axis that consists mainly of a growth hormone (GH), and IGF (insulin-like growth factor) system comprising IGF I-III, the corresponding receptors, and the binding proteins (Bolliet et al. 2001, Pierce et al. 2001, Wang et al. 2008, Berishvili et al. 2010). The structure and functions of the somatotropic axis in fish resemble those described in detail for mammalian species (Duan 1998). Therefore administration of human GH to Prussian carp, Carassius gibelio (Bloch, 1782), accelerated the somatic growth (Cui and Zhu 1993).

Fish GH is a crucial factor which, except for promoting somatic growth, also modifies maturation, water adapta- 
tion, and immunity (Yada et al. 1992, 2001, De-Santis and Jerry 2007, Wuertz et al. 2007, Benedet et al. 2010). Secretion of GH is under control of the growth hormone releasing hormone (GHRH) and its antagonist somatostatin (Canosa et al. 2007, Lakeh et al. 2011). Analyses have shown that in fish, secretion of growth hormone occurs in a pulsatile manner from somatotropic cells and may depend on water temperature, light intensity, reproduction stage, availability and quality of food, or animal health condition (Marchant and Peter 1986, Reddy and Leatherland 1994, Björnsson et al. 2002). In several fish species higher GH concentrations in blood were reported during night and what might have been correlated with higher melatonin levels (Falcón et al. 2003). Kausel et al. (1999) presented that water temperature had a great impact on GH levels in samples of common carp, Cyprinus carpio Linnaeus, 1758.

Tench, Tinca tinca (Linnaeus, 1758), for centuries has been cultivated in Polish fish farms in polycultures with common carp. This way of farming has been applied to increase fairly low growth rate of tench and efficiently utilize pond resources (tench stirs up the mud to find food). (Skrzypczak and Mamcarz 2006). In East Germany in the 20th century a fast growing Quolsdorf tench strain was developed in the course of a long-term selection programme. However, after several years of intensive tench farming, carried out to meet the rising demand for its tasty and delicate meat, the strain disappeared and has never been re-established (Milkau 1921 cited after Panicz et al. 2012, Šestáková et al. 1989, Bilard and Flajshans 1995). Since that time many researchers tried to increase the growth rate of tench. Some of the ways to achieve a higher growth rate included feeding trials in juvenile stages or research on the compensatory growth phenomenon. However, even though at the beginning researchers obtained promising results, it was later discovered that such ideas were generally insufficient to solve that complex problem (Quirós and Alvariño 2000, Wolnicki et al. 2003, 2006, Celada et al. 2008).

The aim of this work was to assess the influence of water temperature on mRNA gh level in pituitary-, liver-, and muscle samples as well as the level of the GH protein in blood and liver samples. An additional aim was to measure IGF-I protein concentration in liver samples. The results have contributed to an enrichment of the current state of knowledge about the functioning of the somatotropic axis in tench and the SSD (Sexual Size Dimorphism) phenomenon.

\section{MATERIALS AND METHODS}

Aquarium trial and sample handling. Forty tench, approximately $3+$ years of age were obtained from the Fisheries Research Station of the West Pomeranian University of Technology (ZUT), Szczecin and transported to the experimental facility of the Division of Aquaculture of the ZUT. There were no statistical differences between groups in their length and weight and the mean weight of individuals at the beginning of the trial was $220 \mathrm{~g}( \pm 10 \mathrm{~g})$. The aquarium trial lasted one week. There were eight $240 \mathrm{~L}$ tanks filled with dechlorinated tap water and representing four temperature regimes $\left(10^{\circ} \mathrm{C}, 15^{\circ} \mathrm{C}, 20^{\circ} \mathrm{C}\right.$, and $\left.25^{\circ} \mathrm{C}\right)$. They were stocked with five fish each. Each temperature regimes was studied separately for each sex. Water in the experimental tanks was prepared two weeks earlier with sufficient oxygen content and appropriate temperature. Fish were not fed during this period of time, were not disturbed, and were protected from any source of light. After this, the fish were anesthetized using Propiscin (etomidate-based product, manufactured by the IRS, Żabieniec, Poland) and 3 males and 3 females were randomly selected from each tank. From each fish specimen $2 \mathrm{~mL}$ of blood, the whole pituitary gland, 2 liver samples and one muscle sample were collected. Total RNA from the pituitary-, liver-, and dorsal muscle samples of each the fish was extracted with TRIzol reagent (Invitrogen) following the manufacturer's protocol. RNA integrity was assessed through separation in a $1.5 \%$ agarose gel and spectrophotometric measurements in a NanoDrop device. Blood samples were stored overnight in $4^{\circ} \mathrm{C}$, centrifuged (4000 rpm for $10 \mathrm{~min}$ ), and the plasma was transferred to new tubes. Additional liver samples, $0.1 \mathrm{~g}$ each, were homogenized in $200 \mu \mathrm{L}$ of phosphate buffered saline (PBS) without $\mathrm{Ca}^{2+}$ and $\mathrm{Mg}^{2+}$ (Dulbecco) with a TissueLyser II (Qiagen), spun down and the liquid phase was transferred to new tubes. The use and handling of animals for this experiment was approved by the Local Ethical Committee for Experiments on Animal (Resolution No. 2/1/2008).

Standard curve and quantification of mRNA $g h$. Standard curves were developed using tmRNA $g h$ transcripts prepared by in vitro transcription based on the sequence for tench growth hormone available at the NCBI database (NCBI Acc. No. HM114351.1). Briefly, total RNA of tench undergone one-step reverse transcription and cDNA transcription was subsequently introduced into the pGEM-T EASY vector (Promega). After multiplication, the insert was sequenced, excised, undergone in vitro transcription with T7 specific primers, purified, and the final concentration of tmRNA $g h$ was determined. In order to develop standard curves, a tmRNA $g h$ stock was decimally diluted five times (tmRNA $g h-21.4,2.14,214,21.4$, and 2.14 $\mathrm{pg} \cdot \mu \mathrm{L}^{-1)}$. The number of mRNA $g h$ transcripts in total RNA samples extracted from pituitary-, liver-, and muscle samples was scored by quantitative real-time RT-PCR according to the tmRNA $g h$ standard curve. The sequence of primers and TaqMan ${ }^{\circledR}$ probe for the qPCR were designed using Primer 3 software, according to instructions found in the papers published by Marino et al. (2003) and Li et al. (2008). The forward primer Tt $3 \mathrm{iF}$ and the TaqMan probe hybridised within the third exon of mRNA $g h$, whereas the reverse primer $\mathrm{Tt} 3 \mathrm{iR}$ hybridised in the region of the junction between the third and the fourth exon. Primer and probe sequences used in this study are listed in Table 1. The amount of mRNA $g h$ of 72 tench samples (3 tissues $\times 6$ fish $\times 4$ temperature regimes) was determined on an Mx3005PTM (Stratagene) thermal cycler. All reactions were performed using the following qRT-PCR conditions: $50^{\circ} \mathrm{C}$ for $30 \mathrm{~min}$ (reverse transcription), $95^{\circ} \mathrm{C}$ for $15 \mathrm{~min}$ (polymerase activation), followed by 40 cycles at $95^{\circ} \mathrm{C}$ for $15 \mathrm{~s}, 55^{\circ} \mathrm{C}$ for $30 \mathrm{~s}$ and $76^{\circ} \mathrm{C}$ for $30 \mathrm{~s}$. On the basis of initial transcript concentrations and obtained cycle threshold $(\mathrm{Ct})$ values from the standard curves, the software of 
the Mx3005PтM thermal cycler automatically calculated the amount of mRNA gh using Ct values measured for the tested samples. Reaction mixtures for standard curves and tench samples were prepared using the QuantiTect Probe RT-PCR Kit (QIAGEN) according to the manufacturer's recommendations.

Measurement of GH and IGF-I levels. GH and IGF-I concentrations in blood and liver samples were measured using competitive ELISA tests, the Fish Growth Hormone (GH), ELISA kit and, in the case of liver samples, the Fish Insulin-Like Growth Factor 1 (IGF-1) ELISA kit (CUSABIO, China). Measurements were performed on an iMark Microplate Absorbance Reader (BioRad), filter $450 \mathrm{~nm}$. Calculations were automatically performed according to a standard curve of known concentrations by the software of the device. The comparison of the mean levels of $\mathrm{Ct}$ values between the sexes and water temperature treatments was performed using the Mann-Whitney U test. Obtained results for ELISA study undergone statistical analysis, LSD (Least Significant Difference), and Levene tests, to assess effect of water temperature on tench GH and IGF-I levels.

\section{RESULTS}

Absolute quantification of mRNA $\boldsymbol{g} \boldsymbol{h}$. RNA extracted from pituitary-, liver-, and muscle samples had a high quality (lack of degradation of major ribosomal RNA bands) and sufficient quantity (500 ng $\left.\cdot \mu \mathrm{L}^{-1}\right)$. The dilution series of tmRNA $g h$ was quantified separately and together with experimental samples by qPCR and showed an acceptable level: $R^{2}=0.990$, efficiency $=99 \%, y=-3.346$. $\log (x)+37.66$. Running tench samples with standard dilutions revealed that complete results for pituitary-, liver-, and muscle samples were achieved only for 3 fish (Table 2). Precisely, data were obtained for 2 males from the tank with $10^{\circ} \mathrm{C}$ water temperature $\left(3 \delta^{\lambda} 10^{\circ} \mathrm{C}\right.$ and $\left.1 \delta^{\lambda} 10^{\circ} \mathrm{C}\right)$ and one female from the tank with $15^{\circ} \mathrm{C}$ water temperature $\left(1+15^{\circ} \mathrm{C}\right)$. The majority of the $\mathrm{Ct}$ values were obtained for pituitary samples, i.e., 23 out of 24 analysed. Only one amplification curve (a sample from the third male incubated at $20^{\circ} \mathrm{C}$ ) did not cross the threshold (lack of Ct value). According to the obtained results, the sample $3925^{\circ} \mathrm{C}$ had the lowest amount of $g h$ encoding mRNA whereas the sample $1 \delta^{\Uparrow} 10^{\circ} \mathrm{C}$ the highest. When we arrange the $\mathrm{Ct}$ values from the lowest to the highest, in the first 10 results $50 \%$ belonged to fish samples obtained from the water at $15^{\circ} \mathrm{C}$. Additionally, in all temperature treatments mean $\mathrm{Ct}$ values estimated for males and females were at com- parable level and no differences were observed between temperature treatments. Results obtained for muscle tissue samples comprised of $10 \mathrm{Ct}$ values, from which 7 originated from females. The highest concentration of mRNA $g h$ in muscle tissue $\left(102.41 \mathrm{pg} \cdot \mu \mathrm{L}^{-1}\right)$ was significantly lower in relation to the maximum concentrations in the pituitary gland samples $\left(37311 \mathrm{pg} \cdot \mu \mathrm{L}^{-1}\right)$. Among the positive results, $70 \%$ belonged to fish from tanks at $10^{\circ} \mathrm{C}$ (4 fish) and at $15^{\circ} \mathrm{C}$ (3 fish), whereas the remaining $30 \%$ belonged to fish kept at $20^{\circ} \mathrm{C}$ (one fish) and $25^{\circ} \mathrm{C} \mathrm{(two} \mathrm{fish).} \mathrm{Only} 3 \mathrm{Ct}$ values were obtained for analysed liver samples that were excised form fish kept in water of $10^{\circ} \mathrm{C}$ (two fish) and $15^{\circ} \mathrm{C}$ (one fish). $\mathrm{Ct}$ values for liver and muscle samples were higher than for pituitary samples, which unambiguously showed that mRNA gh transcript concentrations were much lower there (Table 2).

GH and IGF-I levels. Based on the standard curves produced for GH and IGF-I, absorbance values measured in the unknown samples were used to calculate protein concentrations. Graphs of GH concentrations in plasma and liver samples had a similar shape for both sexes. The highest GH concentrations were observed in tench samples obtained from water at $20^{\circ} \mathrm{C}$ (Figs. 1 and 2). Moreover, $\mathrm{GH}$ concentrations measured for fish kept at a water temperature of $20^{\circ} \mathrm{C}$ was over 8 times higher in blood plasma in comparison to liver samples. The graph for IGF-I concentrations in liver samples displayed interesting results. While water temperature was rising, the concentration of IGF-I in liver was increasing, especially in samples collected from females (Fig. 3).

\section{DISCUSSION}

Effect of water temperature on mRNA $g h$ expression. The sample analysis revealed that the expression of mRNA gh mainly occurred in the pituitary gland of tench (Table 2 ), which coincides with results described by Reinecke et al. (2005). Further analysis did not confirmed that water temperature had a direct effect on the level of mRNA $g h$ expression in tench, probably due to small sample size. However, scientific literature provide examples when somatotropes induce mRNA $g h$ transcription, independently of photoperiod, but depending on temperature. Breton et al. (1980a, 1980b) and Horoszewicz et al. (1981) reported cases related to the water temperature $10^{\circ} \mathrm{C}$, where gonadotropic cells produced gonadotropins which subsequently stimulated growth hormone synthesis and secretion. As water temperature reached $20^{\circ} \mathrm{C}$, the amount of gonadotro-

Table 1

Oligonucleotides and probes used in real-time PCR reactions

Oligo/probe designation
Nucleotide sequence $5^{\prime} \rightarrow 3^{\prime}$

Reference

\begin{tabular}{lll}
\hline EGFP-1-F & GACCACTACCAGCAGAACAC & Hoffmann et al. 2006 \\
EGFP-2-R & GAACTCCAGCAGGACCATG & \\
Probe & HEX-AGCACCCAGTCCGCCCTGAGCA-Q & Presently reported study \\
Tt3iF & GGAACGCAGACAGCTGAGTA & \\
Tt3iA & GGAGCTTCAACATTGAGCTCTTC & \\
Probe & FAM-ACTCTGACTCCATTGAGGCGCCCA-Q & \\
\hline
\end{tabular}


Table 2

Concentration of the growth hormone mRNA in selected tissues of tench, Tinca tinca

\begin{tabular}{|c|c|c|c|c|c|c|c|c|}
\hline & & & \multicolumn{6}{|c|}{ Concentration of GH mRNA $\left[\mathrm{pg} \cdot \mu \mathrm{L}^{-1}\right]$} \\
\hline \multicolumn{3}{|c|}{ Sample } & \multicolumn{2}{|c|}{ Pituitary } & \multicolumn{2}{|c|}{ Muscle } & \multicolumn{2}{|c|}{ Liver } \\
\hline $\mathrm{n}$ & Sex & $T$ & Value & $\mathrm{CT}$ & Value & $\mathrm{CT}$ & Value & $\mathrm{CT}$ \\
\hline$\underline{1}$ & $\hat{\Omega}$ & $10^{\circ} \mathrm{C}$ & $\underline{37311}$ & $\underline{16.78}$ & $\underline{102.41}$ & $\underline{25.35}$ & 1.17 & $\underline{31.85}$ \\
\hline 2 & q & $15^{\circ} \mathrm{C}$ & 32290 & 16.99 & 4.89 & 29.77 & & \\
\hline 2 & q & $20^{\circ} \mathrm{C}$ & 26086 & 17.30 & & & & \\
\hline 1 & q & $25^{\circ} \mathrm{C}$ & 22732 & 17.50 & & & & \\
\hline 1 & $\hat{\sigma}$ & $15^{\circ} \mathrm{C}$ & 15676 & 18.04 & & & & \\
\hline 2 & $\hat{0}$ & $20^{\circ} \mathrm{C}$ & 14836 & 18.12 & & & & \\
\hline 1 & 오 & $\underline{15^{\circ} \mathrm{C}}$ & 12664 & 18.35 & 2.92 & $\underline{30.52}$ & 6.53 & $\underline{29.35}$ \\
\hline 3 & $\hat{0}$ & $15^{\circ} \mathrm{C}$ & 11422 & 18.50 & 12.47 & 28.41 & & \\
\hline 1 & $\widehat{\sigma}$ & $25^{\circ} \mathrm{C}$ & 10810 & 18.58 & & & & \\
\hline 2 & $\hat{0}$ & $15^{\circ} \mathrm{C}$ & 7302 & 19.15 & & & & \\
\hline 1 & q & $10^{\circ} \mathrm{C}$ & 4865 & 19.74 & & & & \\
\hline 2 & $\hat{0}$ & $10^{\circ} \mathrm{C}$ & 4669 & 19.80 & & & & \\
\hline 2 & q & $25^{\circ} \mathrm{C}$ & 4637 & 19.81 & 2.14 & 30.97 & & \\
\hline 3 & $\hat{0}$ & $25^{\circ} \mathrm{C}$ & 3089 & 20.40 & & & & \\
\hline 1 & $\hat{\sigma}$ & $20^{\circ} \mathrm{C}$ & 2462 & 20.73 & & & & \\
\hline 3 & q & $20^{\circ} \mathrm{C}$ & 2428 & 20.75 & & & & \\
\hline 2 & q & $10^{\circ} \mathrm{C}$ & 1844 & 21.15 & 6.90 & 29.27 & & \\
\hline 1 & q & $20^{\circ} \mathrm{C}$ & 527 & 22.97 & 6.57 & 29.34 & & \\
\hline$\underline{3}$ & $\underline{2}$ & $\underline{10^{\circ} \mathrm{C}}$ & 499 & $\underline{23.05}$ & $\underline{17.71}$ & $\underline{27.90}$ & $\underline{6.35}$ & $\underline{29.39}$ \\
\hline 2 & $\hat{\sigma}$ & $25^{\circ} \mathrm{C}$ & $\overline{485}$ & 23.09 & & & & \\
\hline 3 & o & $15^{\circ} \mathrm{C}$ & 456 & 23.18 & & & & \\
\hline 3 & q & $10^{\circ} \mathrm{C}$ & 54 & 26.28 & 3.98 & 30.07 & & \\
\hline 3 & q & $25^{\circ} \mathrm{C}$ & 19 & 27.79 & 121.64 & 25.10 & & \\
\hline
\end{tabular}

$\mathrm{GH}=$ growth hormone, $T=$ temperature, $\mathrm{Ct}=$ cycle threshold, $n=$ number of fish with at least one positive result; Underlined values represent samples with full set of $\mathrm{Ct}$ values ( $\mathrm{Ct}$ for pituitary, liver and muscle).

pin was reduced and therefore the synthesis of mRNA $g h$ decreased. Similar results were described for gilthead seabream, Sparus aurata Linnaeus, 1758, where synthesis and secretion of GH had been observed during the spring period, when the photoperiod became longer and water temperature ranged from 15 to $20^{\circ} \mathrm{C}$ (Pérez-Sánchez et al. 1994). Kausel et al. (1999) also presented results where water temperature had a profound impact on the expression of the growth hormone encoding gene in common carp samples.

Interesting results were obtained for muscle tissue samples where mRNA $g h$ expression was documented. Extensive studies in orange-spotted grouper, Epinephelus coioides (Hamilton, 1822), revealed that growth hormone transcripts were not detected in kidney-, heart-, stomach-, and muscle samples (Li et al. 2005). The authors applied also alternative method to prove their findings, however the obtained results confirmed the previous findings. The data presented in Table 2 prove that in tench muscle an expression of the growth hormone encoding gene exist but on a lower scale compared to pituitary samples from the same individual, where only 10 out of 24 analysed muscle samples were characterized with Ct values (Table 2).
In the case of liver samples, the obtained $\mathrm{Ct}$ values were one of the highest (low amount of mRNA gh) among all obtained in the study. Yang et al. (1999) grouped internal organs of fish based on high and low copy number of mRNA $g h$. This indicated that the pituitary gland, brain, gills, and heart had higher number of mRNA gh copies than kidney, pyloric caeca, gonads, and liver. In the presently reported study, the method for quantification of gene transcription was selected properly, which permitted assessing even low levels of growth hormone gene activity. Temperature effect on tench GH and IGF-I levels. Concentration of $\mathrm{GH}$ in liver and blood samples reached its maximum in individuals kept at $20^{\circ} \mathrm{C}$ and then decreased (Figs. 1 and 2). A similar tendency was observed for gilthead seabream, Sparus aurata Linnaeus, 1758 (see PérezSánchez et al. 1994). According to the above-mentioned authors, the highest $\mathrm{GH}$ concentration at $20^{\circ} \mathrm{C}$ might result from an "immature" conformation state of the Growth Hormone Receptor (GHR), which is unable to bind GH. Later, when the water was heated up to $25^{\circ} \mathrm{C}$, a successful formation of GH-GHR complexes occur and the concentration of GH in blood plasma decreases. Receptor state is 


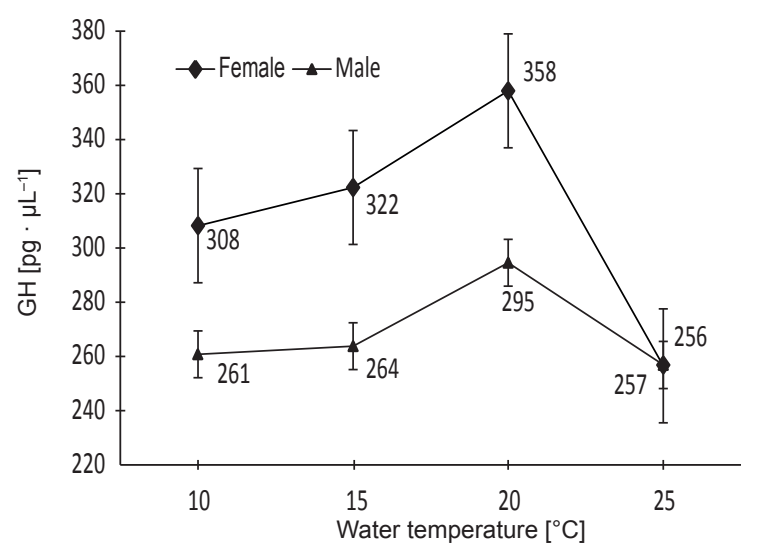

Fig. 1. Growth hormone concentration (GH) in liver samples of tench, Tinca tinca, at different temperatures

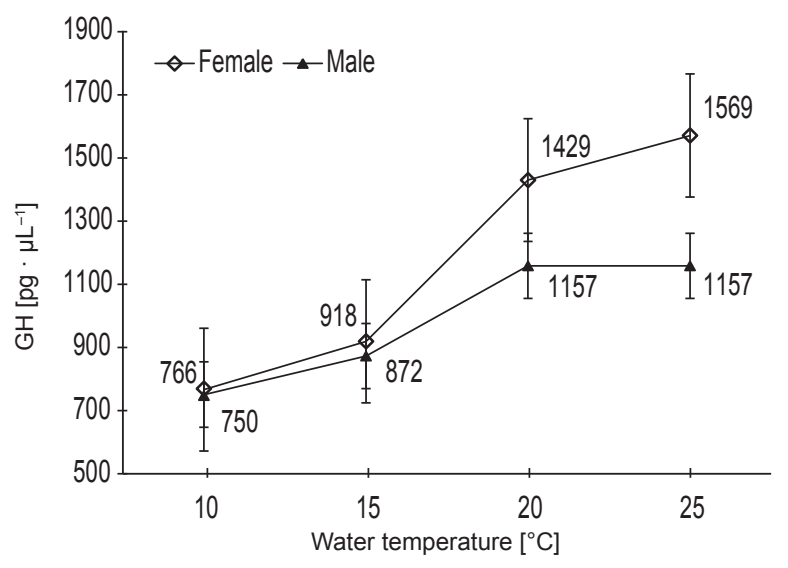

Fig. 2. Growth hormone concentration in plasma samples of tench, Tinca tinca, from different temperatures.

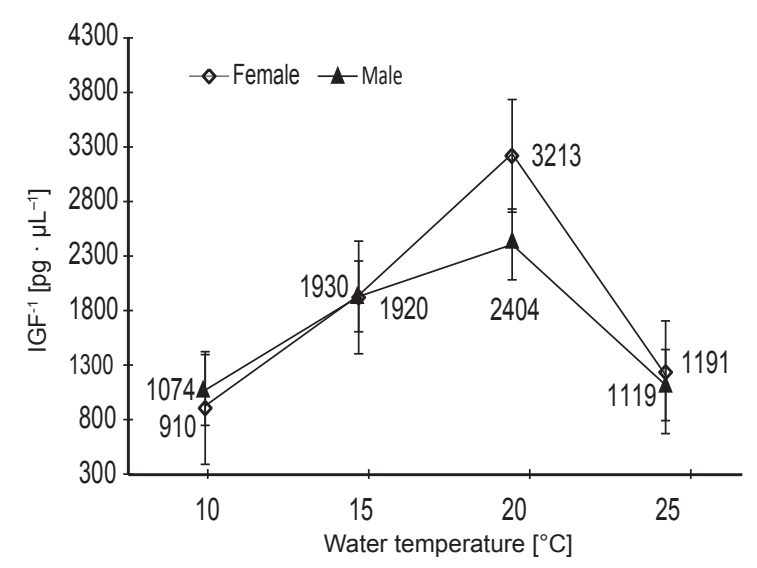

Fig. 3. Insulin-like growth factor 1 concentration in liver samples of tench, Tinca tinca, at different temperatures

one out of many control mechanisms of the somatotropic axis, called receptor resistance (Sumpter et al. 1991, Gray et al. 1992). The scientific literature had pointed out other examples of brown trout, Salmo trutta Linnaeus, 1758 (see Swift 1954); European perch, Perca fluviatilis Linnaeus, 1758 (see Swift and Pickford 1965); goldfish, Carassius auratus (Linnaeus, 1758) (see Marchant and Peter 1986); or gilthead seabream, Sparus aurata (see Pérez-Sánchez et al. 1994) where temperature of water influenced GH level in fish samples. Additionally, the above-mentioned studies indicated that the highest $\mathrm{GH}$ concentration measured in a given water temperature is species-specific. In our study, within all temperature treatments, the values measured for liver samples were lower comparing to those attained for blood plasma samples.

Along with the increase of water temperature, the concentration of IGF-I in tench liver samples also increased. This interdependency generally relates on GH-GHR interactions which trigger the transcription process of mRNA igf-I which is followed by IGF-I synthesis (Pérez-Sánchez et al. 1994). The above-mentioned authors also observed that low concentration of GH and high concentration of IGF-I were positively correlated with the Specific Growth Rate (SGR) and the Protein Efficiency Ratio (PER) in fish. The results obtained in the presently reported study showed that at $25^{\circ} \mathrm{C}$ the $\mathrm{GH}$ concentration dropped to the same level as at $10^{\circ} \mathrm{C}$, whereas the IGF-I concentration in liver samples was the highest among all treatments. Low concentrations of GH observed in plasma samples might be explained by negative feedback exerted by IGF-I on the growth hormone. It has been found that IGF-I stimulates the production of somatostatin, which in turn affects production and secretion of the growth hormone (Canosa et al. 2007). In another case, Fraser et al. (2002) observed that an increase of water temperature activated the transcription of the GABA factor, which in effect arrested the secretion of GH from the pituitary gland.

Sexual size dimorphism of tench. The present paper considered also a well described phenomenon of fish SSD with respect to the results obtained for tench. The SSD in tench was for the first time described by Nordquist (1927; cited after Wang et al. 2006). The above author noted that in the second year of tench culture females grew faster than males and suggested that it was probably connected with sexual maturation. In yellowtail flounder, Limanda ferruginea (Storer, 1839), females grew faster, attained larger sizes, and had a longer lifespan than males as a reason of energy surplus channelling. In the case of males, energetic outlay on reproduction took place two years earlier, compared to females. Males attained smaller sizes and had a shorter life span (Dwyer et al. 2003). The scientific literature has documented many other examples of females growing faster than males and vice versa (Imsland et al. 1997, Bonnet et al. 1999).

The SSD phenomenon in terms of the presented results may be considered against $\mathrm{Ct}$ values measured for muscle tissue. The majority of the obtained $\mathrm{Ct}$ results (70\%) referred to females whereas $30 \%$ referred to males. In the results obtained for the pituitary gland and liver there were no differences between values referring to males and females. It is difficult to state explicitly that females might grow faster than males. However, based on GH and IGF-I concentrations we could generally assume that values for females were higher in relation to males what was observed for GH concentrations measured in liver samples 
excised from fish kept in water at $20^{\circ} \mathrm{C}$ (more than eight time difference).

\section{REFERENCES}

Benedet S., Andersson E., Mittelholzer C., Taranger G.L., Björnsson B.T. 2010. Pituitary and plasma growth hormone dynamics during sexual maturation of female Atlantic salmon. General and Comparative Endocrinology 167 (1): 77-85.

DOI: 10.1016/j.ygcen.2010.02.011

Berishvili G., Baroiller J.-F., Eppler E., Reinecke M. 2010. Insulin-like growth factor-3 (IGF-3) in male and female gonads of the tilapia: Development and regulation of gene expression by growth hormone $(\mathrm{GH})$ and $17 \alpha$-ethinylestradiol (EE2). General and Comparative Endocrinology 167 (1): 128-134.

DOI: $10.1016 /$ j.ygcen.2010.01.023

Billard R., Flajshans M. 1995. The current state of research and culture of tench, Tinca tinca Linnaeus (1758). Concluding remarks on the workshop. Polish Archives of Hydrobiology 42 (1-2): 219-225.

Björnsson B.T., Johansson V., Benedet S., Einarsdottir I.E., Hildahl J., Agustsson T., Jönsson E. 2002. Growth hormone endocrinology of salmonids: Regulatory mechanism and mode of actions. Fish Physiology and Biochemistry 27 (3): 227-242.

DOI: 10.1023/B:FISH.0000032728.91152.10

Bolliet V., Aranda A., Boujard T. 2001. Demand-feeding rhythm in rainbow trout and European catfish; Synchronisation by photoperiod and food availability. Physiology and Behavior 73 (4): 625-633.

DOI: 10.1016/S0031-9384(01)00505-4

Bonnet S., Haffray P., Blanc J.M., Vallée F., Vauchez C., Fauré A., Fauconneau B. 1999. Genetic variation in growth parameters until commercial size in diploid and triploid freshwater rainbow trout (Oncorhynchus mykiss) and seawater brown trout (Salmo trutta). Aquaculture 173 (1-4): 359-375.

DOI: $10.1016 / \mathrm{S} 0044-8486(98) 00460-8$

Breton B., Horoszewicz L., Bieniarz K., Epler P. 1980a. Temperature and reproduction in tench: Effect of a rise in the annual temperature regime on gonadotropin level, gametogenesis and spawning. II. The female. Reproduction Nutrition Développement 20 (4A): 10111024.

DOI: $10.1051 / \mathrm{rnd}: 19800610$

Breton B., Horoszewicz L., Billard R., Bieniarz K. 1980b. Temperature and reproduction in tench: Effect of a rise in the annual temperature regime on gonadotropin level, gametogenesis and spawning. I. The male. Reproduction Nutrition Développement 20 (1A): 105-118.

DOI: $10.1051 / \mathrm{rnd}: 19800106$

Canosa L.F., Chang J.P., Peter R.E. 2007. Neuroendocrine control of growth hormone in fish. General and Comparative Endocrinology 151 (1): 1-26.

DOI: $10.1016 /$ j.ygcen.2006.12.010

Celada J.D., Aguilera A., Carral J.M., Saez-Royuela M., Melendre P.M. 2008. Rearing tench (Tinca tinca
L.) larvae on live feed (Artemia) and on two transition schedules from live to dry diets. Journal of Applied Ichthyology 24 (5): 595-600.

DOI: $10.1111 /$ j.1439-0426.2008.01078.x

Chang J.P., Wong A.O.L. 2009. Growth hormone regulation in fish: A multifactorial model with hypothalamic, peripheral and local autocrine/paracrine signals. Pp. 151-195. In: Farrell A.P., Brauner C.J. (eds.) Fish Physiology Vol. 28, Chapter 4. Elsevier.

Cui Z., Zhu Z. 1993. Hormonal replacement therapy in fish - human growth-hormone gene-function in hypophysectomized carp. Fish Physiology and Biochemistry 12 (?): 161-169.

DOI: $10.1007 / \mathrm{BF} 00004381$

De-Santis C., Jerry D.R. 2007. Candidate growth genes in finfish-Where should we be looking? Aquaculture 272 (1-4): 22-38.

DOI: $10.1016 /$ j.aquaculture.2007.08.036

Duan C. 1998. Nutritional and developmental regulation of insulin-like growth factors in fish. Journal of Nutrition 128 (2): 306S-314S.

Dwyer K.S., Walsh S.J., Campana S.E. 2003. Age determination, validation and growth of Grand Bank yellowtail flounder (Limanda ferruginea). ICES Journal of Marine Sciences 60 (5): 1123-1138.

DOI: $10.1016 / \mathrm{S} 1054-3139(03) 00125-5$

Falcón J., Besseau L., Fazzari D., Attia J., Gaildrat P., Beauchaud M., Boeuf G. 2003. Melatonin modulates secretion of growth hormone and prolactin by trout pituitary glands and cells in culture. Endocrinology 144 (10): 4648-4658.

DOI: 10.1210/en.2003-0707

Fraser E.J., Bosma P.T., Trudeau V.L., Docherty K. 2002. The effect of water temperature on the GABAergic and reproductive systems in female and male goldfish (Carassius auratus). General and Comparative Endocrinology 125 (2): 163-175.

DOI: $10.1006 /$ gcen.2001.7714

Gray E.S., Kelley K.M., Law S., Tsai R., Young G., Bern H.A. 1992. Regulation of hepatic growth hormone receptors in coho salmon (Oncorhynchus kisutch). General and Comparative Endocrinology 88 (2): 243-252. DOI: 10.1016/0016-6480(92)90256-J

Handeland S.O., Imsland A.K., Stefansson S.O. 2008. The effect of temperature and fish size on growth, feed intake, food conversion efficiency and stomach evacuation rate of Atlantic salmon post-smolts. Aquaculture 283 (1-4): 36-42.

DOI: $10.1016 /$ j.aquaculture.2008.06.042

Horoszewicz L., Bieniarz K., Epler P. 1981. Effect of different thermal regimes on reproductive cycles of tench Tinca tinca (L.). Part IV. Duration and temperature of spawnings. Polish Archives of Hydrobiology 28 (2): 207-216.

Imsland A.K., Folkvord A., Grung G.L., Stefansson S.O., Taranger G.L. 1997. Sexual dimorphism in growth and maturation of turbot, Scophtalmus maximus (Rafinesque, 1810). Aquaculture Research 28 (2): 101-114. 
DOI: 10.1046/j.1365-2109.1997.t01-1-00829.x

Jobling M. 2002. Environmental factors and rates of development and growth. Pp: 97-122. In: Hart P.J.B., Renynolds J.D. (eds.) Handbook of fish biology and fisheries. Vol. 1. Fish Biology. Chapter 5. Blackwell Publishing.

DOI: $10.1002 / 9780470693803 . c h 5$

Kausel G., Vera M.I., San Martin R., Figueroa J., Molina A., Muller M., Martial J., Krauskopf M. 1999. Transcription factor Pit-1 expression is modulated upon seasonal acclimatization of eurythermal ectotherms: Identification of two Pit-1 genes in carp. Journal of Cellular Biochemistry 75 (4): 598-609.

DOI: 10.1002/(SICI)1097-4644(19991215)75:4<598::AIDJCB6>3.0.CO;2-J

Kullgren A., Jutfelt F., Fontanillas R., Sundell K., Samuelsson L., Wiklander K., Kling P., Koppe W., Larsson D.G.J., Björnsson B.T., Jönsson E. 2013. The impact of temperature on the metabolome and endocrine metabolic signals in Atlantic salmon (Salmo salar). Comparative Biochemistry and Physiology Part A: Molecular and Integrative Physiology 164 (1): 44-53.

DOI: 10.1016/j.cbpa.2012.10.005

Lakeh A.A.B., Farahmand H., Mirvaghefi A., Kloas W., Peterson B.C., Wuertz S. 2011. GH and IGF-I induction by passive immunisation of rainbow trout Oncorhynchus mykiss (Walbaum) using a somatostatin-14 antibody. Aquaculture 316 (1-4): 99-103. DOI: 10.1016/j.aquaculture.2011.02.029

Li J., Smyth P., Cahill S., Denning K., Flavin R., Aherne S., Pirotta M., Guenther S.M., O'Leary J.J., Sheils O. 2008. Improved RNA quality and TaqMan ${ }^{\circledR}$ pre-amplification method (PreAmp) to enhance expression analysis from formalin fixed paraffin embedded (FFPE) materials. BMC Biotechnology 8: 10 . DOI: $10.1186 / 1472-6750-8-10$

Li W.S., Chen D., Wong A.O.L., Lin H.R. 2005. Molecular cloning, tissue distribution, and ontogeny of mRNA expression of growth hormone in orange-spotted grouper (Epinephelus coioides). General and Comparative Endocrinology 144 (1): 78-89.

DOI: 10.1016/j.ygcen.2005.04.018

Mader M.M., Cameron D.A. 2004. Photoreceptor differentiation during retinal development, growth, and regeneration in a metamorphic vertebrate. Journal of Neurosciences 24 (50): 11463-11472.

DOI: $10.1523 /$ JNEUROSCI.3343-04.2004

Marchant T.A., Peter R.E. 1986. Seasonal variations in body growth rates and circulating levels of growth hormone in the goldfish, Carassius auratus. Journal of Experimental Zoology 237 (2): 231-239.

DOI: $10.1002 /$ jez.1402370209

Marino J.H., Cook P., Miller K.S. 2003. Accurate and statistically verified quantification of relative mRNA abundances using SYBR Green I and real-time RTPCR. Journal of Immunological Methods 283 (1-2): 291-306.

DOI: 10.1016/S0022-1759(03)00103-0
Mustapha M.K., Okafor B.U., Olaoti K.S., Oyelakin O.K. 2012. Effects of three different photoperiods on the growth and body coloration of juvenile African catfish, Clarias gariepinus (Burchell). Archives of Polish Fisheries 20 (1): 55-59.

DOI: $10.2478 / \mathrm{v} 10086-012-0007-1$

Panicz R., Sadowski J., Drozd R. 2012. Genetic and structural characterization of the growth hormone gene and protein from tench, Tinca tinca. Fish Physiology and Biochemistry 38 (6): 1645-1653.

DOI: $10.1007 / \mathrm{s} 10695-012-9661-\mathrm{x}$

Pérez-Sánchez J., Martí-Palanca H., Le Bail P.-Y. 1994. Seasonal changes in circulating growth hormone (GH), hepatic GH-binding and plasma insulin-like growth factor-I immunoreactivity in a marine fish, gilthead sea bream, Sparus aurata. Fish Physiology and Biochemistry 13 (3): 199-208.

DOI: $10.1007 / \mathrm{BF} 00004358$

Pierce A.L., Beckman B.R., Shearer K.D., Larsen D.A., Dickhoff W.W. 2001. Effects of ration on somatotropic hormones and growth in coho salmon. Comparative Biochemistry and Physiology Part B: Biochemistry and Molecular Biology 128 (2): 255-264. DOI: 10.1016/S1096-4959(00)00324-9

Quirós M., Alvariño J.M.R. 2000. Growth and survival of tench larvae fed under different feeding strategies. Journal of Applied Ichthyology 16 (1): 32-35. DOI: 10.1046/j.1439-0426.2000.00155.x

Reddy P.K., Leatherland J.F. 1994. Does the time of feeding affect the diurnal rhythms of plasma hormone and glucose concentration and hepatic glycogen content of rainbow trout? Fish Physiology and Biochemistry 13 (2): 133-140.

DOI: $10.1007 / \mathrm{BF} 00004338$

Reinecke M., Björnson B.T., Dickkhoff W.W., McCormick S.D., Navarro I., Power D.M., Gutiérrez J. 2005. Growth hormone and insulin-like growth factors in fish: Where we are and where to go. General and Comparative Endocrinology 142 (1-2): 20-24. DOI: $10.1016 /$ j.ygcen.2005.01.016

Swift D.R. 1954. Influence of mammalian growth hormone on rate of growth of fish. Nature 173 (4414): 1096.

DOI: $10.1038 / 1731096 a 0$

Swift D.R., Pickford G.E. 1965. Seasonal variations in the hormone content of the pituitary gland of the perch, Perca fluviatilis L. General and Comparative Endocrinology 5 (3): 354-365.

DOI: 10.1016/0016-6480(65)90060-2

Šestáková I., Kouřil J., Faina R., Vachta R. 1989. Age dependence of tench (Tinca tinca L.) larvae on food selectivity in experimental conditions. Buletin VÚRH Vodniany 25 (4): 3-11.

Skrzypczak A., Mamcarz A. 2006. Changes in commercially exploited populations of tench, Tinca tinca (L.), in littoral zones of lakes of northeastern Poland. Aquaculture International 14 (1): 171-177. DOI: $10.1007 / \mathrm{s} 10499-005-9023-0$ 
Sumpter J.P., Le Bail P.Y., Pickering A.D., Pottinger T.G., Carragher J.F. 1991. The effect of starvation on plasma growth hormone concentrations of rainbow trout, Oncorhynchus mykiss. General and Comparative Endocrinology 83 (1): 94-102.

DOI: 10.1016/0016-6480(91)90109-J

Sumpter J.P. 1992. Control of growth of rainbow trout (Oncorhynchus mykiss). Aquaculture 100 (1-3): 299320.

DOI: 10.1016/0044-8486(92)90386-Y

Wang D.-S., Jiao B., Hu C., Huang X., Liu Z., Cheng C.H.K. 2008. Discovery of a gonad-specific IGF subtype in teleost. Biochemical and Biophysical Research Communications 367 (2): 336-341.

DOI: $10.1016 /$ j.bbrc.2007.12.136

Wang J.X., Liu H.J., Min W.Q., Tong J., Guan M., Han Y.Z., Gong L.J., Huang Z., Ren J., Zhang J.P., Zheng H.P. 2006. Induced meiotic gynogenesis in tench, Tinca tinca (L.) using irradiated heterogenic sperm. Aquaculture International 14: 35-40.

DOI: $10.1007 / \mathrm{s} 10499-005-9012-3$

Viadero R.C. 2005. Factors affecting fish growth and production. Pp. 129-133. In: Lehr J.H., Keeley J. (eds.) Water Encyclopedia. Vol. 3. Surface and Agricultural Water. John Wiley and Sons.

DOI: 10.1002/047147844X.sw241

Wolnicki J., Myszkowski L., Kaminski R. 2003. Effect of supplementation of a dry feed with natural food on growth, condition and size distribution of juvenile tench Tinca tinca (L.). Journal of Applied Ichthyology 19 (3): 157-160.

DOI: 10.1046/j.1439-0426.2003.00468.x

Wolnicki J., Myszkowski L., Korwin-Kossakowski M., Kamiński R., Stanny L.A. 2006. Effects of different diets on juvenile tench Tinca tinca (L.) reared under controlled conditions. Aquaculture International 14 (1): 89-98.

DOI: $10.1007 / \mathrm{s} 10499-005-9017-y$

Wuertz S., Gessner J., Kirschbaum F., Kloas W. 2007. Expression of IGF-I and IGF-I receptor in male and female sterlet, Acipenser ruthenus-Evidence for an important role in gonad maturation. Comparative Biochemistry and Physiology Part A: Molecular and Integrative Physiology 147 (1): 223-230. DOI: $10.1016 /$ j.cbpa.2006.12.031

Yada T., Azuma T., Takagi Y. 2001. Stimulation of non-specific immune functions in seawater-acclimated rainbow trout, Oncorhynchus mykiss, with reference to the role of growth hormone. Comparative Biochemistry and Physiology Part B: Biochemistry and Molecular Biology 129: 659-701. DOI: $10.1016 / \mathrm{S} 1096-4959(01) 00370-0$

Yada T., Kobayashi T., Urano A., Hirano T. 1992. Changes in growth hormone and prolactin messenger ribonucleic acid levels during seawater adaptation of amago salmon (Onchorhynchus rhodurus). Journal of Experimental Zoology 262 (4): 420-425.

DOI: $10.1002 /$ jez. 1402620408

Yang B.-Y., Greene M., Chen T.T. 1999. Early embryonic expression of the growth hormone family protein genes in the developing rainbow trout, Oncorhynchus mykiss. Molecular Reproduction and Development 53 (2): 127-134.

DOI:10.1002/(SICI)1098-2795(199906)53:2<127::AIDMRD1>3.0.CO;2-H

Received: 30 December 2014

Accepted: 29 September 2015

Published electronically: 31 December 2015 